\title{
Aspects of knowledge
}

Preserving and reinventing traditions of learning in the Middle Ages

EDITED BY MARILINA CESARIO

AND HUGH MAGENNIS

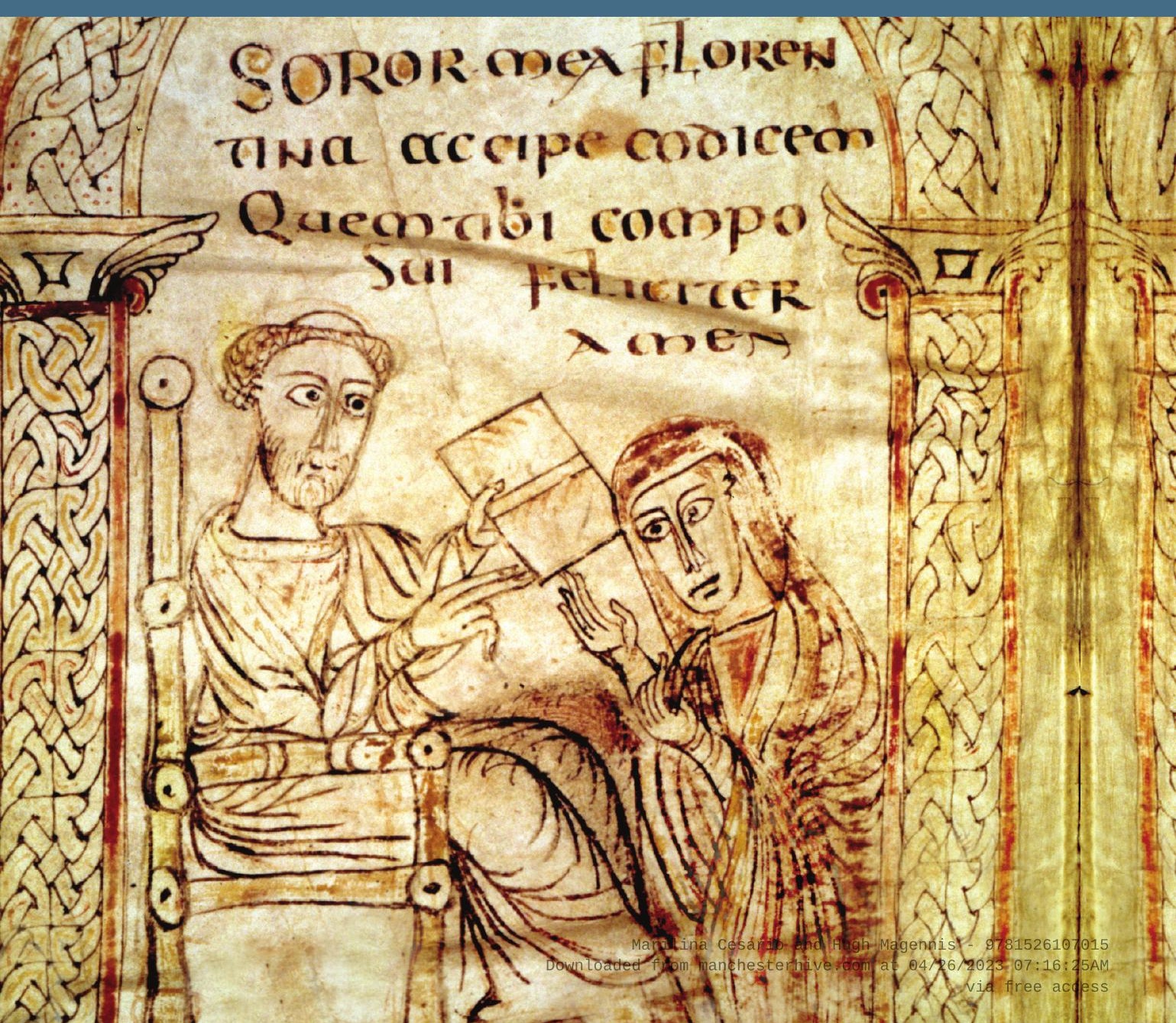




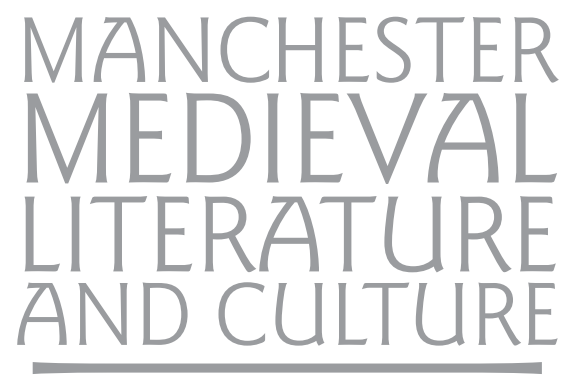

ASPECTS OF KNOWLEDGE

\section{MANCHESTER 1824}

Manchester University Press 
Series editors: Anke Bernau, David Matthews, James Paz

Series founded by: J. J. Anderson and Gail Ashton

Advisory board: Ruth Evans, Nicola McDonald, Andrew James Johnston, Sarah Salih, Larry Scanlon and Stephanie Trigg

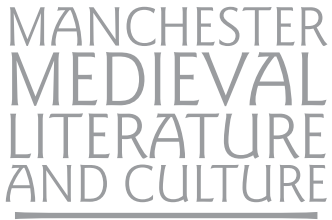

Manchester Medieval Literature and Culture publishes

monographs and essay collections comprising new research informed by current critical methodologies on the literary cultures of the Middle Ages. We are interested in all periods, from the early Middle Ages through to the late, and we include post-medieval engagements with and representations of the medieval period (or 'medievalism'). 'Literature' is taken in a broad sense, to include the many different medieval genres: imaginative, historical, political, scientific, religious. While we welcome contributions on the diverse cultures of medieval Britain and are happy to receive submissions on Anglo-Norman, Anglo-Latin and Celtic writings, we are also open to work on the Middle Ages in Europe more widely, and beyond.

\section{Titles Available in the Series}

5. In strange countries: Middle English literature and its afterlife: Essays in memory of

\section{J.J. Anderson}

David Matthews (ed.)

6. A knight's legacy: Mandeville and Mandevillian lore in early modern England Ladan Niayesh (ed.)

7. Rethinking the South English Legendaries Heather Blurton and Jocelyn Wogan-Browne (eds)

8. Between earth and heaven: Liminality and the Ascension of Christ in Anglo-Saxon literature Johanna Kramer

9. Transporting Chaucer Helen Barr

10. Sanctity as literature in late medieval Britain Eva von Contzen and Anke Bernau (eds)

11. Reading Robin Hood: Content, form and reception in the outlaw myth Stephen Knight

12. Annotated Chaucer bibliography: 1997-2010 Mark Allen and Stephanie Amsel

13. Roadworks: Medieval Britain, medieval roads Valerie Allen and Ruth Evans (eds)

14. Love, history and emotion in Chaucer and Shakespeare: Troilus and Criseyde and Troilus and Cressida Andrew James Johnston, Russell West-Pavlov and Elisabeth Kempf (eds)

15. The Scottish Legendary: Towards a poetics of hagiographic narration Eva von Contzen

16. Nonhuman voices in Anglo-Saxon literature and material culture James Paz

17. The church as sacred space in Middle English literature and culture Laura Varnam 


\section{Aspects of knowledge}

Preserving and reinventing traditions of learning in the Middle Ages

Edited by

MARILINA CESARIO AND HUGH MAGENNIS

Manchester University Press 
While copyright in the volume as a whole is vested in Manchester University Press, copyright in individual chapters belongs to their respective authors, and no chapter may be reproduced wholly or in part without the express permission in writing of both author and publisher.

Published by Manchester University Press

Altrincham Street, Manchester M1 7JA

www.manchesteruniversitypress.co.uk

British Library Cataloguing-in-Publication Data

A catalogue record for this book is available from the British Library

ISBN 9780719097843 hardback

First published 2018

The publisher has no responsibility for the persistence or accuracy of URLs for any external or third-party internet websites referred to in this book, and does not guarantee that any content on such websites is, or will remain, accurate or appropriate.

Typeset by

Servis Filmsetting Ltd, Stockport, Cheshire 